\title{
Praca w jednym ujęciu, czyli historia aktywności zawodowych XXI wieku widziana okiem kamery
}

W roku 2011 Antje Ehmann i Harun Farocki rozpoczęli międzynarodowy cykl warsztatów poświęconych zagadnieniu pracy. Chodziło w nim o stworzenie serii jednoujęciowych filmów trwających nie więcej niż dwie minuty, które opowiadałyby o aktywności zawodowej typowej lub też mniej typowej dla danego kraju czy miasta. Na dzień dzisiejszy zostało zrealizowanych dziesięć warsztatów na planowanych piętnaście. Reprezentująca Polskę Łódź była dziewiątym miejscem-miastem.

Jednym z ważniejszych założeń projektu jest stworzenie bazy filmowej[1], która ma stanowić nietypowe kompendium wiedzy na temat tego, co współcześnie myśli się i wyobraża na temat pracy. Ma być rodzajem krótkich rejestracji filmowych mówiących o wybranych zawodach XXI wieku. Jak do tej pory proces badań na wyobrażeniach o pracy został zrealizowany w Hanoi, Moskwie, Buenos Aires, Rio de Janeiro, Kairze, Berlinie, Tel Awiwie, Genewie, Bangalore, Lizbonie i Łodzi. Pomimo tak dużego rozstrzału kulturowego język filmowy i historia filmu stanowił wspólny mianownik w sposobie formułowania pracy twórczej i w procesie przebiegu warsztatów. Jedynie polityczne podejście artystów różnych krajów miało znaczenie różnicujące i zmieniało atmosferę podczas spotkań. Zwłaszcza w Kairze, w mieście rozpalonym rewolucją antyrządową, twórcy zatroskani byli przede wszystkim tym, co mogliby za pomocą tych filmów przekazać światu, jakie znaczenie będzie miała ta specyficzna narracja, którą wybiorą, i czy poza podstawowym celem projektu mogą stworzyć własny, związany z rewolucyjnym nastrojem przekaz.

Propozycja realizacji warsztatów w Polsce pojawiła się ze strony Instytutu Goethego, który patronuje temu projektowi we wszystkich piętnastu krajach. W momencie, gdy już było wiadomo, że Antje i Harun przyjadą do Polski, Łódź stała się naturalnym wyborem przede wszystkim za sprawą PWSFTViT, ponieważ projekt ten realizowany jest zazwyczaj we współpracy z najważniejszymi ośrodkami filmowymi danego kraju. Muzeum Sztuki w Łodzi, reprezentowane przez kuratorki Aleksandrę Jach i Joannę Sokołowską, w którym odbędzie się finałowa wystawa podsumowująca pracę warsztatową polskiej edycji, też nie zostało wybrane przez przypadek. Po pierwsze

[1] Już teraz można obejrzeć ponad dwieście krótkich form wideo umieszczonych na dedykowanej projek- towi stronie: <http://www.labour-in-a-single-shot. net/en/films/> [dostęp: 13 czerwca 2013]. 
kilka lat wcześniej Muzeum współpracowało już z Harunem Farockim, organizując retrospektywę jego twórczości filmowej (Pracując na marginesach, 2010), po drugie zaś tematyka krążąca wokół zagadnienia pracy jest obecna w praktyce muzealnej łódzkiego ms2 od dłuższego czasu.

O tym, co wyobrażone

Kulisy powstania
projektu
Projekt ten w dużej mierze oparty jest na wyobrażeniach na temat pracy i w tym tkwi jego siła. $Z$ założenia powstałe prace filmowe nie odnoszą się do statystyki, nie chodzi tu o najbardziej zgodną z rzeczywistością reprezentację prac typowych dla danego miasta. Zaproszeni do projektu filmowcy czy artyści sztuk wizualnych sami decydują, jaki rodzaj pracy chcieliby przedstawić i niekoniecznie musi on być mocno związany z wizerunkiem miasta. Oczywiście na pewnym poziomie ważnym aspektem jest również pokazanie tej specyfiki danego miejsca, ale autorzy projektu z premedytacją nie zmieniają tematów uczestników, nie regulują kierunku rozwoju projektu na poziomie treści. Postawienie sprawy warsztatu tak, by pracować $\mathrm{z}$ wizerunkami, $\mathrm{z}$ reprezentacją czy - idąc tym tropem nieco dalej - z poszukiwaniem ideologii za wyobrażeniem, jest typowym zabiegiem artystycznym dla twórczości Farockiego. Czasem to, co myślimy o danym zjawisku, mówi dużo więcej niż zabiegi kreacyjne oparte na bazie danych, zwłaszcza gdy mowa o badaniach na tkance społecznej. Dopiero zderzenie powstałych prac ze statystyką, dokonujące się już na wystawie podsumowującej efekty pracy każdego z miast, generuje pewną wiedzę. Poza pokazem realizacji filmowych na każdej wystawie można obejrzeć i porównać przygotowane wcześniej raporty oparte na profesjonalnych badaniach statystycznych, dotyczące bezrobocia i statystyk pracowych. Rozdźwięk czy przesunięcie pozwala wtedy dostrzec tak naprawdę stan faktyczny - niezgodność lub też niedopasowanie, a może nawet luki, w tym, jak jest - w porównaniu $\mathrm{z}$ tym, jak postrzegamy czy chcielibyśmy widzieć jedną z ważniejszych aktywności w przestrzeni działań społecznych: pracę - w systemie, w którym żyjemy.

Przyczyn powstania projektu było kilka. Podobnie trochę jak z klasyczną serią zbiegów okoliczności, które ostatecznie składają się na ukształtowanie konkretnego, wielowątkowego pomysłu. Harun Farocki, pracując w latach 2006-2011 jako profesor Akademii Sztuk Pięknych w Wiedniu, zapoczątkował zajęcia, które w swej koncepcji były zbliżone do pomysłu „Pracy w jednym ujęciu”[2]. Jak sam podkreśla, idea ta sprawdziła się wśród studentów na tyle, że zaczął realizować ten projekt $\mathrm{w}$ kilku innych miejscach. Jednocześnie wraz z Antje Ehmann, partnerką życiową i zawodową, od dłuższego czasu planowali realizację jakiegoś wspólnego, dłuższego przedsięwzięcia. W ostatnim roku nauczania przez Haruna na Akademii uznali, że to idealny moment na rozwinięcie międzynarodowego projektu, który

[2] <http://www.farocki-film.de/> [dostęp: 13 czerwca

2013]. 
pozwalałby im wspólnie tworzyć, podróżować oraz jednocześnie godzić obowiązki profesorskie Haruna jako gościa-wykładowcy masterclass w innych krajach.

Kwestia poruszonej tematyki była prawie jednoznaczna, choć wiadomo, że pojawiały się pomysły alternatywne. Temat pracy dla samego Haruna Farockiego jest niezmiernie istotny i towarzyszy mu od wielu lat w jego praktyce artystycznej. Dodatkowo punkt odniesienia warsztatów, czyli rozpoczynający w roku 1895 historię kina film braci Lumière Robotnicy opuszczają fabrykę Lumière, jest również punktem odniesienia dla filmu, który Harun Farocki zrealizował jeszcze w roku 1995, o wymownym tytule: Arbeiter verlassen die Fabrik. Ten oparty na found footage kolaż filmowy odnosi się do dwóch istotnych zagadnień, które w pewien sposób również pojawiły się w obecnym projekcie: do ikoniczności sposobu narracji - określonego sposobu prowadzenia bohatera, który wychodzi z ciemności w przestrzeń oświetloną. Gest ten stał się w historii kina w pewnym sensie ikonicznym sposobem narracji. Widać w nim jednoznacznie początek i koniec połączony z określoną dramaturgią wypełniania kadru filmowego. Druga kwestia dotyczy treści. Wyjście robotników z ciemności w jasną przestrzeń popołudniowego słońca symbolizuje problem tego, co widzialne i niewidzialne. Czas wolny, a w tym i film, zaczyna się wtedy, kiedy kończy się praca, ukryta w czterech ścianach budynku.

Poza tematyką pracy Antje i Harun rozważali również temat czasu wolnego jako bohatera warsztatu. Ciekawe wydało im się postawienie pytania, jak współcześnie podchodzimy do czasu poza pracą, jak go zagospodarowujemy? Czy bardziej skupiamy się na wypoczynku aktywnym, czy może realizujemy wtedy inne zadania? Śledząc podejście ludzi $\mathrm{w}$ różnych regionach świata, można by uzyskać całkiem interesujący obraz dla tej tematyki, ale, jak podkreśla Harun, nie byłoby to tak istotne w swoim wydźwięku jak właśnie zbiór wypowiedzi dotyczących tematu pracy. W końcu to właśnie uwikłanie w pracę łączy ludzi na całym świecie dużo mocniej niż czas wolny. Niezależnie od tego, czy ma się pracę, czy nie, to jest to ten istotny punkt odniesienia dla każdego. Drugim tematem konkurencyjnym było zagadnienie gier i zabaw, czyli nieco bardziej zawężona tematyka czasu wolnego. Obszar również niebagatelny do badania, ale i tym razem niedostatecznie polityczny, niepozwalający wytworzyć odpowiedniego narzędzia, które pomogłyby zrozumieć socjologiczne i ekonomiczne zmiany w społeczeństwie. Praca w tym zakresie staje się dużo bardziej pożądanym tematem, kluczem do zrozumienia przemian zachodzących w tkance społecznej, jej ekonomicznych i politycznych aspektach[3].

[3] J. Rifkin, Koniec pracy, tłum. E. Kania, Wydawnictwo Dolnośląskie, Wrocław 2003; M. Tomba, Zróżnicowania wartości dodatkowej we współczesnych formach wyzysku, tłum. W. Marzec, w: Wieczna radość.
Ekonomia polityczna społecznej kreatywności, Bęc Zmiana, Warszawa 2011; M. Weber, Etyka protestancka a duch kapitalizmu, tłum. B. Baran, P. Miziński, Aletheia, Warszawa 2011. 


\section{Założenia pracy artystycznej}

Kilka ważniejszych wytycznych realizacji projektu stanowiło rodzaj formalnego szkieletu estetycznego, pozwalającego zespolić wszystkie prace w serię, tak by wspomniana już wcześniej baza filmowa uzyskała przejrzystą formę prezentacji. Tak jak już wcześniej pisałam, przede wszystkim filmy nie mogły być dłuższe niż dwie minuty oraz, co zdaje się ważniejsze, miały być zrealizowane jednym ujęciem. Zasady te, po pierwsze, nawiązują w sposób oczywisty do strategii realizacji pierwszych filmów braci Lumière, po drugie zaś - są rodzajem kontestacji współczesnej formy przekazu, która praktycznie prawie zawsze zawiera w sobie wszelkie możliwe dane dotyczace wybranego zagadnienia $\mathrm{w}$ formie pomnożonej i zwielokrotnionej. Innymi słowy, chodziło o zawężenie pola informacyjnego obrazu, dzięki czemu odbiorca musiałby uruchomić wyobraźnię i wyimaginować pewne "przed” i pewne „po" - tzw. resztę, tworzącą całość danego zjawiska. Dziś w świecie permanentnej symulacji i pomnażania obrazów praktycznie nie ma przekazu medialnego, który nie byłby komentowany, opisywany i dopowiadany przez obraz. To - jak sami autorzy nazwali - apodyktyczne podejście do tego projektu miało na celu podkreślenie wartości i znaczenia obrazu i filmowanej historii. Każdy $\mathrm{z}$ realizatorów miał zmierzyć się z tematem tak, jakby miał do dyspozycji kamerę na drogą taśmę filmową. Chodziło o dokładne i ostrożne dokonanie wyboru tematyki, kadru, perspektywy i oświetlenia. Tego typu obostrzenie miało na celu uniknięcie dziś potocznego, szybkiego, pozbawionego często intencji filmowania. Skupienie i uwaga, precyzja oglądu oraz świadomy wybór pozwalają bardziej uważnie skupić się na myśleniu obrazem. Wracając jeszcze do kwestii długości, czyli limitu dwóch minut - jak mówi Antje -

Można byłoby spokojnie sobie wyobrazić, że filmy te miałyby minutę lub trzy, ale doświadczenie podpowiada, że właśnie owe dwie minuty są najbardziej optymalne. Zazwyczaj uczestnicy warsztatów woleliby, by czas rejestracji był nieco dłuższy, tak by bez obaw móc zawrzeć opowieść początek, środek i koniec oraz oczywiście jakąś dramaturgię danego zawodu. Z początku, jeśli nie operujesz na co dzień kamerą i nie masz opartego na doświadczeniu wyczucia czasu widzianego okiem kamery, to te dwie minuty wydają się bardzo krótkim odcinkiem czasu, dopiero $\mathrm{w}$ trakcie realizacji okazuje się, że to całkiem spory odcinek, który prowokuje wiele wariacji ujęć, kompozycji i sposobu narracji. Poza tym, biorąc pod uwagę punkt odniesienia warsztatów, czyli filmy braci Lumière, te dwie minuty stanowią dużo dłuższy czas realizacyjny, gdyż ich filmy zazwyczaj miały około 40 sekund[4].

Wspomniane zasady, czy może bardziej obostrzenia, stanowią również programowy sposób pracy samych artystów. Zarówno Harun Farocki, jak i Antje Ehmann za każdym razem, podchodząc do kolejnego projektu filmowego, budują wstępną listę czynności, których nie należy robić. Tego typu zabiegi, tak zwane reguły negatywne, tak

[4] Wywiad z Antje Ehmann i Harunem Farockim, przeprowadzony podczas warsztatu w Łodzi. 
naprawdę dają większą możliwość ruchu w działaniu i ułatwiają artyście pracę. Dobrym przykładem unaoczniającym tego typu proces sposób konstruowania zasad negatywnych w trakcie realizacji filmu jest Pięć nieczystych zagrań Larsa von Triera. Tematyką filmu jest tu dosłownie realizacja pięciu wariacji krótkometrażowego filmu Jorgena Letha - The perfect Human (Det Perfekte Menneske, 1967) według ustalonych wcześniej reguł negatywnych. Lars von Trier wraz ze swoim mistrzem - duńskim twórcą kina dokumentalnego i eksperymentalnego - powtarzają dwunastominutowy film Letha $\mathrm{z}$ lat 70., narzucając jednocześnie $\mathrm{z}$ każdym kolejnym filmem innego rodzaju obostrzenia i zasady kreacji. Efekt jest taki, że oglądając film dokumentujący rezultat tych pięciu wersji poznajemy warsztat twórczy działania artysty oparty właśnie na liście negatywnych reguł. Jednoznacznie z niego wynika, że to właśnie owa lista buduje ciekawy język filmowy i wyjątkowy charakter kolejnych wariacji. Wracając na grunt projektu w kontekście opisywanego tu problemu, warto wspomnieć, że w trakcie spotkań warsztatowych w Łodzi odbyły się dodatkowe zajęcia w stylu masterclass, na których Harun przeprowadził bezpośrednią analizę swojej pracy twórczej na przykładzie In comparison. Zrealizowany w roku 2009 film opowiada o sposobie wytwarzania cegieł w różnych krajach świata. Ze względu na długi proces realizacyjny tego filmu jedną z głównych zasad stała się dla autora Arbeiter verlassen die Fabrik higiena pracy. By uniknąć kumulacji zebranego materiału, Farocki skupił się na rejestrowaniu jedynie tych ujęć, które potencjalnie mogły wejść do filmu, omijając tym samym filmowanie np. codziennego życia swoich bohaterów, choć, jak sam podkreślał, było to niezmiernie kuszące. Poza tym, po każdym zakończonym procesie realizacyjnym $\mathrm{w}$ danym kraju i przed rozpoczęciem kolejnych ujęć w innym miejscu Harun przechodził do wstępnego porządkowania materiału i montażu. Nawet jeśli montaż ten nie był ostateczny, to stanowił bardzo dobry szkielet do końcowej wersji.

Do polskiej edycji projektu „Praca w jednym ujęciu” zostało zaproszonych dziewiętnastu twórców sztuk wizualnych - studentów i absolwentów łódzkiej Szkoły Filmowej. Całe warsztaty trwały około dwóch tygodni (6-19 maja 2013) i zakończyły się roboczym pokazem wybranych prac. Ostateczna, finalna prezentacja odbędzie się w okolicach 4 października 2013 roku w Muzeum Sztuki w Łodzi.

Proces warsztatowy podzielony był na kilka etapów. Poza wstępną prezentacją założeń projektu ważnym elementem warsztatów były spotkania oparte na wspólnym oglądaniu i analizowaniu powstających prac. Bieżący komentarz całej grupy, a przede wszystkim prowadzących, pozwalał od razu zweryfikować odpowiednie kadrowanie, światło czy dramaturgię świeżo powstałych filmów. Zarówno Antje, jak i Harun są świetnymi liderami i pedagogami w zakresie twórczego prowadzenia grupy. Luźna, a jednocześnie bardzo mocno 
skupiona na aktywności twórczej, atmosfera pozwalała intensywnie rozwijać warsztatowe działania.

Wśród tematów pojawiających się jako propozycje można było przede wszystkim wyróżnić kategorie prac rzemieślniczych, w tym m.in. takie reprezentacje zawodowe, jak: szewc, kucharz, mechanik samochodowy czy dentysta. Powstało także kilka prac nawiązujących do tradycji regionu łódzkiego, czyli do miasta fabryk i centrum przemysłu włókienniczego, oraz filmy prezentujące mniej oczywiste, a za to należące bardziej do obszaru nietypowych aktywności zawodowych - prace typu etat w zoo czy fryzjer dla psów. Zabrakło jednak reprezentacji pracy intelektualnej, nieformalnej czy tzw. niewidzialnej. W trakcie podsumowujących warsztaty rozmów z uczestnikami oraz kuratorkami projektu zostało wysnutych kilka hipotez, czemu tak się dzieje. Przede wszystkim, co bardzo ciekawe, warto nadmienić, że ten problem nie dotyczy jedynie polskiej edycji warsztatów. Właściwie w tych ośmiu krajach, w których odbył się warsztaty jeszcze przed Łodzią, większość uczestników skupiła się na prezentacji pracy rzemieślniczej, fizycznej, opartej dużo bardziej na rękodziele, na pracy, która kojarzona jest $\mathrm{z}$ pewnym standardem produktywności. Biorąc pod uwagę fakt, że żyjemy w czasach hegemonii pracy niematerialnej, ten stan rzeczy, pokazujący, że to właśnie praca niematerialna, intelektualna ma w projekcie szczątkową reprezentację wizualną, jest godny uwagi i zastanowienia. Jedna z hipotez dotyczyła kwestii efektywności pracy samych uczestników warsztatu. Perspektywa filmowania pracy intelektualnej, jak twierdzi Harun, może grozić nudą w zakresie budowania napięcia dramaturgicznego. „Jeśli mamy zarejestrować kogoś siedzącego przed komputerem, kto tylko stuka w klawiatu-

Fot. Mikołaj Zacharow

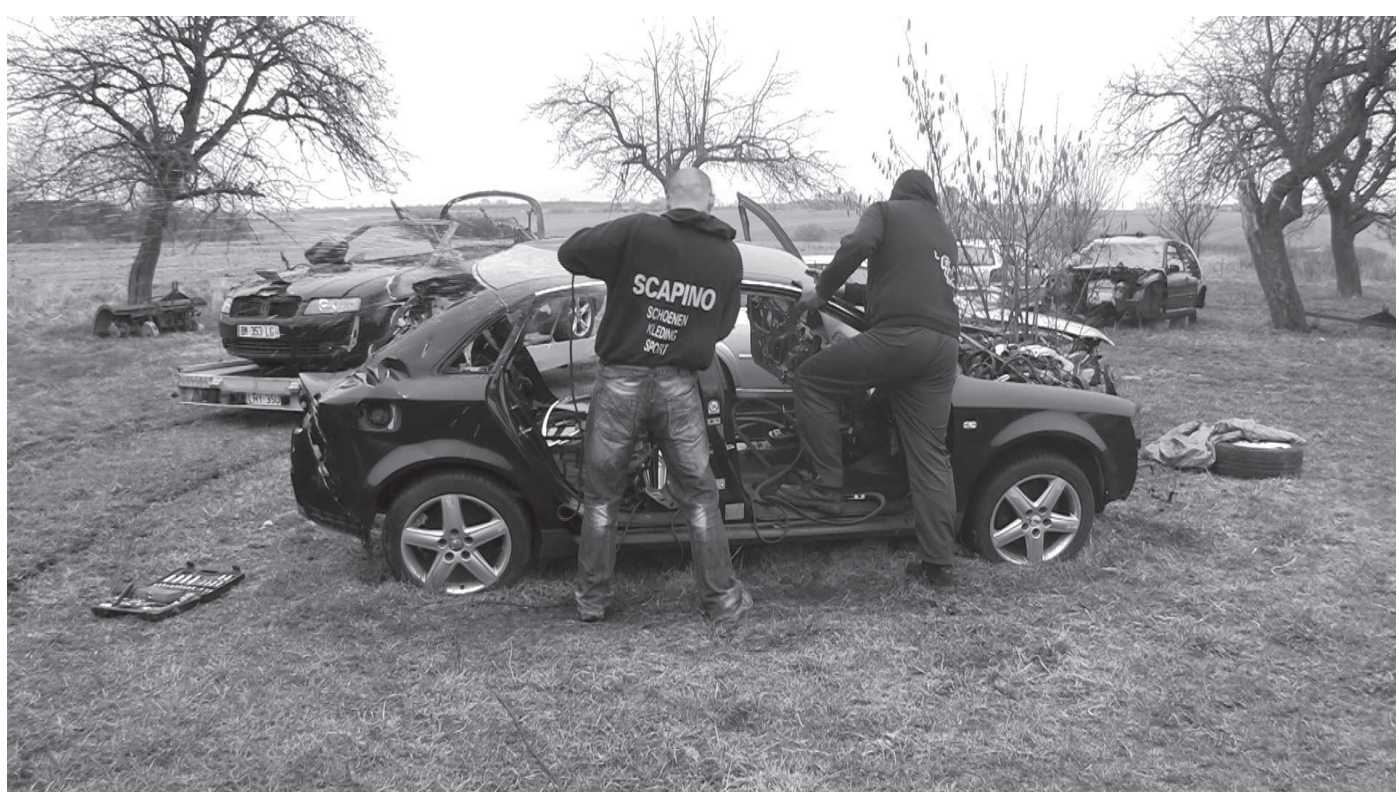




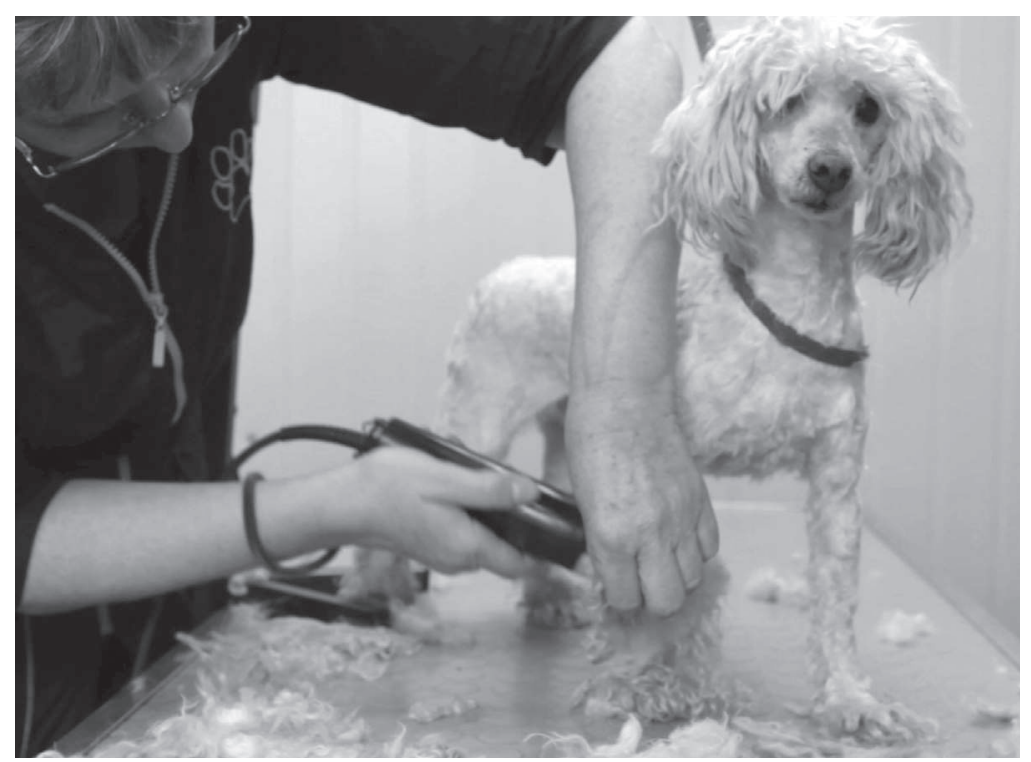

rę, to ciężko będzie stworzyć z tego dwuminutowy film z wyraźnym początkiem, końcem i dramaturgią". Dodatkowo Antje wysnuła jeszcze jedną istotną kwestię, która może wiązać się z tym problemem, mianowicie chodzi o klasyczny podział klasowy społeczeństwa i zainteresowania, jakie z tego tytułu płyną. Artyści i filmowcy, z którymi współpracowali, reprezentują klasę średnią, dla której ciekawsze może wydać się obserwowanie klasy pracującej z niższych sfer.

W Buenos Aires część uczestników skupiła się np. na podglądaniu pracowników zajmujących się wywozem śmieci. Mogło chodzić w tym o to, by móc zaobserwować i przyjrzeć się czemuś z bliska, czego się do tej pory nie miało szans obserwować

- argumentuje Antje Ehmann. Najbardziej chyba istotna i kluczowa hipoteza jest związana z panującym przekonaniem o istnieniu pewnych określonych cech, które praca musi spełniać, by być pracą pełnowartościową w społecznym odbiorze. Chodzi mianowicie o to, że praca powinna być związana z np. zatrudnieniem, rentownością czy płatnością. Praca niematerialna nadal kojarzona jest z czymś z pogranicza aktywności niezawodowej, z obszarem hobby czy tzw. działalnością „inną". Brak namacalnego towaru jako produktu końcowego pracy bardzo często obniża poczucie wartości danej pracy w społecznym odbiorze. Dlatego też kuratorki z Muzeum Sztuki wierzą, że ten projekt ma szansę częściowo zdemitologizować obraz pracy jako takiej, ma szanse przełamać i na poziomie lokalnym, i na poziomie globalnym pewne wyobrażenie na temat pracy zwłaszcza niematerialnej chociażby przez sam fakt unaocznienia tego problemu i sprowokowania dyskusji wokół. Jak podkreśla jedna z kuratorek, Aleksandra Jach:

Nadal nie istnieje w ogólnej świadomości społecznej wiedza, o czym pisze m.in. Donna Haraway, że tak naprawdę praca niematerialna wymaga 
dużo bardziej skomplikowanej infrastruktury i procedur niż praca materialna[5].

Patrząc na stworzoną za sprawą Antje i Haruna bazę filmów, będących reprezentacją aktywności zawodowych w świecie, stwierdzić można, że projekt „Praca w jednym ujęciu” ma potencjał zdemitologizowania i zdemistyfikowania pewnych hierarchii i kategorii, które są nieadekwatne do opisu współczesnej nam rzeczywistości w zakresie pojmowania pracy. Możliwość ta wydaje się niezwykle nagląca i pożądana zwłaszcza dziś, w okresie nadal rozwijającego się kryzysu ekonomicznego i rosnącego bezrobocia w wielu krajach świata.

[5] Wywiad z Aleksandrą Jach i Joanną Sokołowską, przeprowadzony podczas warsztatu w Łodzi. 